\title{
VARIABILITY OF CERTAIN MORPHOLOGICAL CHARACTERISTICS OF LEAVES OF EUROPEAN BEECH (Fagus sylvatica L.) OF FIVE PROVENANCES IN PART OF ITS NATURAL RANGE IN BOSNIA AND HERZEGOVINA
}

\section{Varijabilnost nekih morfoloških svojstava lista 5 provenijencija evropske bukve} (Fagus sylvatica L.) iz dijela prirodnog areala Bosne i Hercegovine

\author{
Sead Ivojević ${ }^{1}$, Ćemal Višnjić ${ }^{1}$, Faruk Mekić ${ }^{1}$
}

\begin{abstract}
This paper deals with the morphological variability of beech leaves (Fagus sylvatica L.) of various provenances in part of its natural range in Bosnia and Herzegovina. The aim of the study was to determine whether beech leaves of various provenances in Bosnia and Herzegovina demonstrate morphological variability, and whether the morphology of beech leaves is an inherited characteristic or is influenced by the habitat conditions of a given provenance.

Following an examination of the morphological characteristics of the beech leaves of each provenance, both intra-provenance and inter-provenance variability of certain leaf characteristics was identified, among both naturally regenerated specimens and seedlings raised from seed from the same provenance.

As regards heredity and morphological leaf characteristics, no correlation was identified between the morphology of leaves of specific provenance and the equivalent nursery-raised seedlings. This suggests that the majority of the morphological parameters of beech leaves are not inherited, and that beech in Bosnia and Herzegovina is a fairly variable and adaptive species.
\end{abstract}

Key words: beech, provenance, morphological characteristics, variability

\section{INTRODUCTION - Uvod}

The preliminary results of the Second Forest Inventory of Bosnia and Herzegovina, the field surveys of which were carried out between 2006 and 2009, reveal that the total area of forest is 3,231,500 ha, of which beech forest accounts for $1,054,600$ ha, or $32.63 \%$. In addition, beech as a forest tree occurs in both coniferous and deciduous woodland in beech and fir forest with spruce, covering an area of 762,800 ha or $23.61 \%$ of the total forested area of Bosnia and Herzegovina. The

\footnotetext{
${ }^{1}$ Faculty of Forestry University of Sarajevo
} 
combined figures of pure and mixed stands of beech reveal that beech as a species is represented in more than half the total forested area of this country.

This suggests that beech is a very important species economically in Bosnia and Herzegovina. In addition, given the area it covers, and the number of communities it constitutes with other important tree species, it is extremely important from the ecological perspective. Beech plays an invaluable part in preserving the stability of our forest ecosystems and in maintaining forest soils and diversity; hence its welldeserved epithet "mother of the forest."

The morphological and phenological variability of beech was widely studied in Europe in the $20^{\text {th }}$ century. The shape of the crown is very variable, depending on the branching, branch insertion, and leaf size and shape (MUSH, 1986; RICHTER, 1990).

The time of bud-burst of early and late flushing beech has been found to differ by as much as two weeks, even within the same stand.

Six trials from eleven provenances of common beech were conducted in Poland in 1964 (RZEZNIK, 1976). The trials monitored differences in the growth rate, phenology and morphology of the leaves. The trials also revealed two provenance ecotypes in Poland: a lowland ecotype and an upland ecotype.

More recent research has shown that there are significant differences between different populations as regards such morphological characteristics as the type of crown, the branching, and the appearance of the bark, leaves and so on. Three types of crown were identified: straight, forked and besom-like (ARNSWALDT 1950, KRAHLURBAN 1953, VeSELY 1977). Significant correlation between crown characteristics and branch density was found, particularly as regards the angle of insertion of the branches (BEZAČINSKÝ 1975). An assessment of the heredity pattern $\left(h^{2}=0.66\right)$ of spiral grain fibre deviation in 30-year-old progeny found a strong additive genetic control (TEISSIER DU CROSS ET AL. 1980). A strong correlation was found in older stands between fibre deviation and bark characteristics. The bark of common beech is typically smooth, but differences in bark colour and smoothness were found in various parts of its range, and beech with grooved bark has been described (F. quercoides Pers.). Differences have also been identified at the population level as regards the length and breadth of the leaf blade and the length of the petiole (Mıšı́ 1956, 1957, PAGAN 1968).

\section{MATERIAL AND METHODS - Materijal i metode}

The material used for the study consisted of leaves of six provenances of beech from Bosnia and Herzegovina originating from various eco-climatic areas and different altitudes, as detailed in Table 1.

Leaf material was collected in 2008 from natural progeny of the provenances studied, with the exception of the Banja Luka provenance; the results for the morphology of leaves from natural populations are therefore given for five provenances. Leaf material was also collected from one-year-old seedlings from five provenances raised at the Sedrenik nursery. The seeds from the Bosansko Grahovo 
provenance did not germinate, and were thus excluded from the experiment. The specimens from which leaves were collected for examination were selected by random sample both in the wild and in the nursery.

Table 1. Basic details of the beech provenances studied

Tabela 1. Osnovni podaci o istraživanim provenijencijama bukve

\begin{tabular}{|c|l|l|l|l|}
\hline No. & Provenance & Site & Altitude (m) & $\begin{array}{l}\text { Geographical } \\
\text { coordinates }\end{array}$ \\
\hline 1. & Bužim & "Glinica" & $300-350$ & $45^{\circ} 05^{\prime} \mathrm{N}, 16^{\circ} 05^{\prime} \mathrm{E}$ \\
\hline 2. & Bugojno & "Skrta-Nišan" & $600-700$ & $43^{\circ} 50^{\prime} \mathrm{N}, 17^{\circ} 25^{\prime} \mathrm{E}$ \\
\hline 3. & Banja Luka* & "Osmača-Tisovac" & $630-780$ & $44^{\circ} 39^{\prime} \mathrm{N}, 17^{\circ} 10^{\prime} \mathrm{E}$ \\
\hline 4. & Bos. Grahovo** & "Peulje" & $830-850$ & $42^{\circ} 40^{\prime} \mathrm{N}, 18^{\circ} 40^{\prime} \mathrm{E}$ \\
\hline 5. & Posušje & "Bosiljna" & $950-1050$ & $43^{\circ} 28^{\prime} \mathrm{N}, 17^{\circ} 20^{\prime} \mathrm{E}$ \\
\hline 6. & Olovo & "Patkovac" & $950-1050$ & $44^{\circ} 10^{\prime} \mathrm{N}, 18^{\circ} 30^{\prime} \mathrm{E}$ \\
\hline
\end{tabular}

* leaf material not collected from natural progeny

** leaf material not collected from nursery seedlings

The leaf material collected from the sites in the wild was taken from progeny up to $1.30 \mathrm{~m}$ in height. In both cases, natural populations and nursery stock, the leaves were taken from the upper part of the crown, specifically the third leaf from the top of a shoot. In order to study the morphological characteristics of the leaves, the leaves were herbarized before taking the following measurements in the traditional manner:

1. length of leaf (blade + petiole)

2. length of leaf blade

3. length of petiole

4. width of blade

5. distance from tip to widest part of the leaf

6. angle of insertion of the second right-hand vein from the base on the back of the leaf

7. presence of cilia on the leaf margin

Parameters 1 and 5 were measured using a digital calliper (precision 0.01 $\mathrm{mm}$ ); parameter 6 was measured with a protractor; parameter 7 was determined under magnifying glass and accorded one of three values: $0=$ no cilia; $2=$ a few cilia; $3=$ many cilia. 


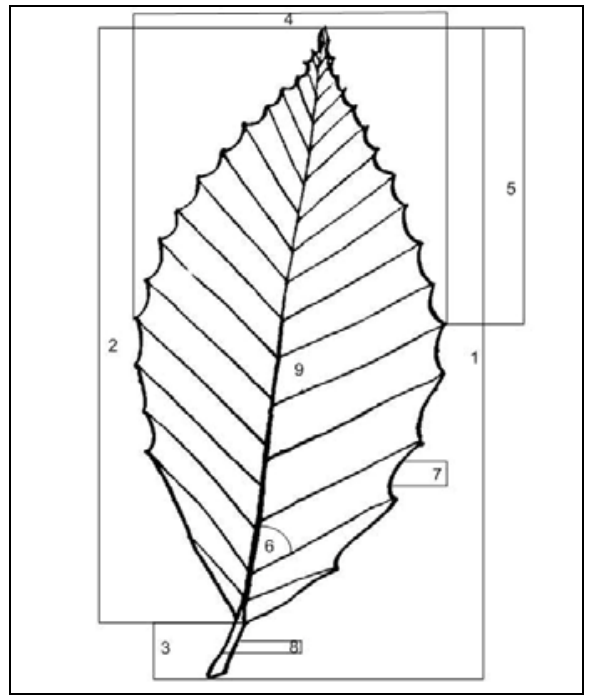

Fig 1. Morphological indicators measured on leaf material (1 - length of leaf, 2 - length of leaf blade, 3 -length of petiole, 4 -width of leave, 5 -distance from leaf tip to widest point of the leaf, 6 angle of insertion of the second right-hand vein from the base, from the back, 7-presence of cilia on the leaf margin, 8 -thickness of petiole, 9 - surface area of the leaf)

Slika 1. Mjereni morfološki pokazatelji na lisnom materijalu (1 - dužina lista, 2 - dužina lisne plojke, 3 - dužina peteljke lista, 4 - širina lista, 5 -odstojanje od vrha do najšireg dijela lista, 6-ugao insercije drugog desnog nerva, odozdo, sa naličja, 7 - prisustvo dlačica na rubu lista, 8 - debljina peteljke, 9 - površina lista)

\section{RESULTS - Rezultati}

Leaf length was measured on 30 leaves from each of five provenances from natural progeny and one-year-old nursery-raised seedlings. The results are shown in the following figures and tables:

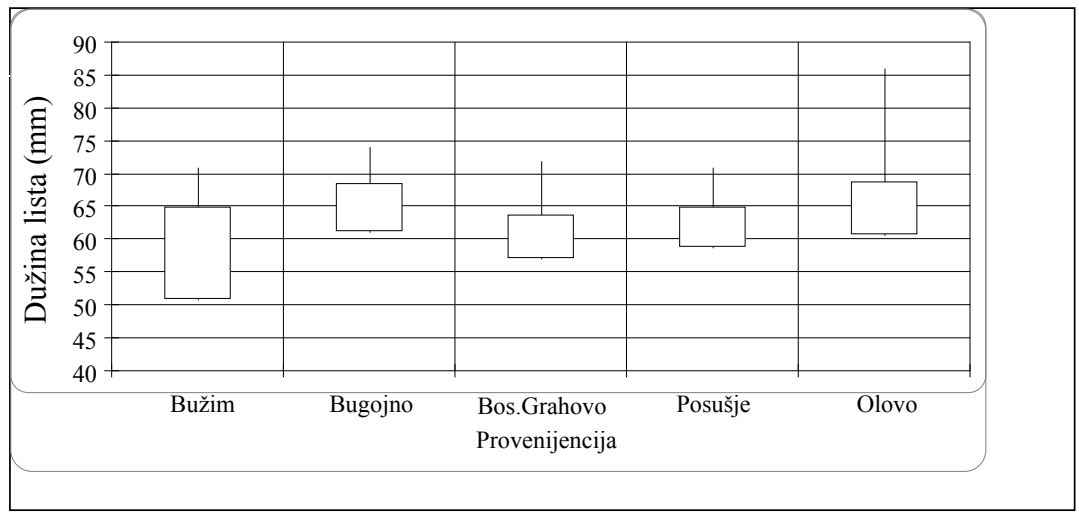

Chart 1. Length of leaves of natural progeny by provenance

Grafikon 1. Dužina listova prirodnog podmlatka po provenijencijama 
Chart 1 shows that the shortest average leaf length was on leaves of Grahovo provenance, followed by Posušje and Bužim provenances, while the Olovo and Bugojno provenances yielded the longest leaves from natural progeny.

Table 2. Variance analysis of leaf length of natural progeny, by provenance (Xsr.= arithmetic mean, St.dev.= standard deviation, $\mathrm{VC}=$ variance coefficient)

Tabela 2. Analiza varijanse dužine listova prirodnog podmlatka po provenijencijama (Xsr.= aritmetička sredina, St.dev. = standardna devijacija, VK= varijacioni koeficijent)

\begin{tabular}{|l|l|c|c|c|c|c|}
\hline No. & Provenance & $\mathrm{N}$ & Xsr. $(\mathrm{mm})$ & St.dev. & $\begin{array}{c}\text { VC } \\
(\%)\end{array}$ & $\begin{array}{c}\text { Duncan } \\
\text { group }\end{array}$ \\
\hline 1. & Grahovo & 30 & 63.77 & 4.15 & 6.50 & $\mathrm{a}$ \\
\hline 2. & Bužim & 30 & 64.85 & 3.26 & 5.02 & $\mathrm{a}$ \\
\hline 3. & Posušje & 30 & 64.85 & 3.26 & 5.02 & $\mathrm{a}$ \\
\hline 4. & Bugojno & 30 & 68.37 & 3.43 & 5.02 & $\mathrm{~b}$ \\
\hline 5. & Olovo & 30 & 68.71 & 5.68 & 8.26 & $\mathrm{~b}$ \\
\hline \multicolumn{2}{|l|}{ Sum/mean value } & 150 & 66.11 & 3.95 & 5.97 & - \\
\hline
\end{tabular}

Significance level 0.05

Variance analysis was applied to determine statistically significant differences between the characteristics observed, with very small variance coefficients. For leaf length of natural progeny, the provenances formed two Duncan groups differing statistically in leaf length: the Olovo and Bugojno provenances with longer leaves, and the Bosansko Grahovo, Bužim and Posušje provenances with shorter leaves.

The results obtained from the analysis of leaves from nursery seedlings were as follows. The Bugojno provenance had the shortest leaves on one-year-old seedlings, closely followed by the Posušje and Bužim provenances. The Banja Luka provenance had the longest seedling leaves, with those from the Olovo provenance slightly shorter (Chart 2).

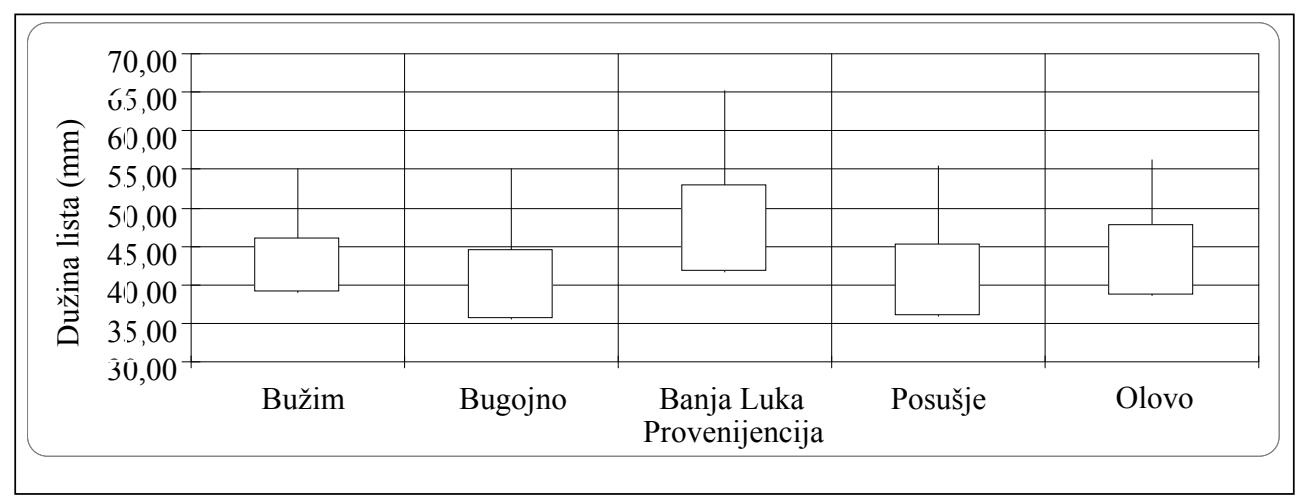

Chart 2. Length of leaves of seedlings by provenance

Grafikon 2. Dužina listova klijanaca po provenijencijama 
Table 3. Variance analysis of leaf length of seedlings, by provenance (Xsr.= arithmetic mean, St.dev. $=$ standard deviation, $\mathrm{VC}=$ variance coefficient)

Tabela 3. Analiza varijanse dužine listova klijanaca po provenijencijama (Xsr. = aritmetička sredina, St.dev. $=$ standardna devijacija, $V K=$ varijacioni koeficijent)

\begin{tabular}{|l|l|c|c|c|r|c|}
\hline No. & Provenance & $\mathrm{N}$ & Xsr. $(\mathrm{mm})$ & St.dev. & VC (\%) & $\begin{array}{c}\text { Duncan } \\
\text { group }\end{array}$ \\
\hline 1. & Bugojno & 30 & 44.49 & 4.92 & 11.06 & $\mathrm{a}$ \\
\hline 2. & Posušje & 30 & 45.27 & 5.69 & 12.57 & $\mathrm{a}, \mathrm{b}$ \\
\hline 3. & Bužim & 30 & 46.02 & 4.26 & 9.25 & $\mathrm{a}, \mathrm{b}$ \\
\hline 4. & Olovo & 30 & 47.83 & 4.41 & 9.22 & $\mathrm{~b}$ \\
\hline 5. & Banja Luka & 30 & 52.88 & 6.86 & 12.97 & $\mathrm{c}$ \\
\hline \multicolumn{2}{|l|}{ Sum/mean value } & 150 & 47.30 & 5.23 & 11.02 & - \\
\hline
\end{tabular}

Significance level 0.05,

$\mathrm{F}=11.9861$

The variance analysis revealed statistically significant differences between the Banja Luka, Olovo and Bugojno provenances. The Bugojno provenance had the longest leaves, while the shortest were from the seedlings from Banja Luka. The Posušje and Bužim provenances belong to a single Duncan group, falling in leaf length between the Bugojno and Olovo provenances in the case of the leaf length of seedlings raised at the Sedrenik nursery.

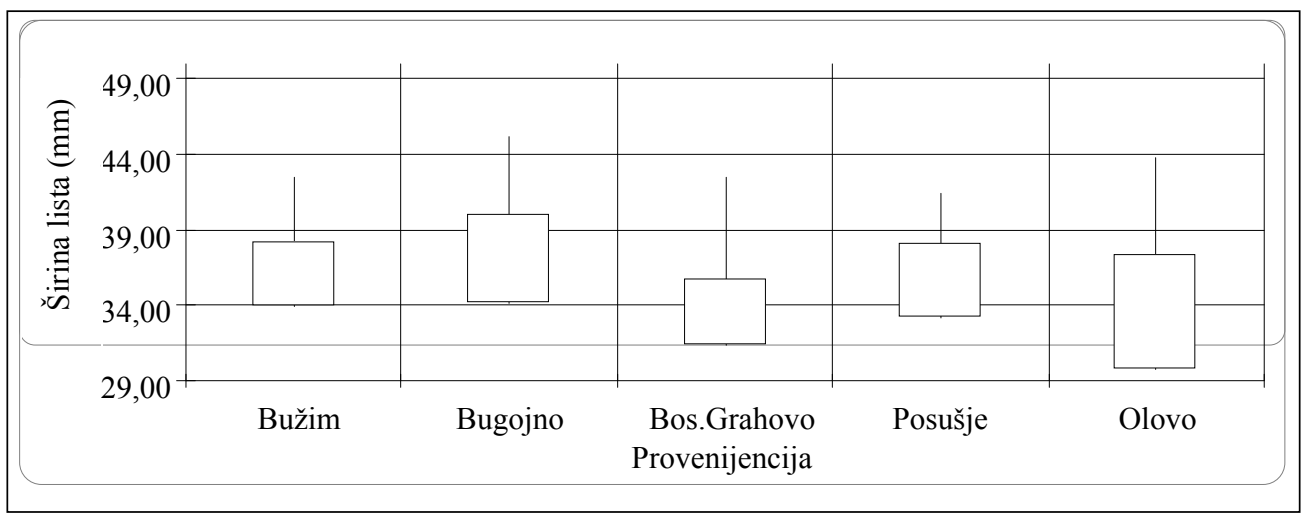

Chart 3. Width of leaves of natural progeny by provenance

Grafikon 3. Širina listova prirodnog podmlatka po provenijencijama

The mean value for the leaf width of natural progeny from the provenances studied lies within deviation limits of $4.24 \mathrm{~mm}$. The provenance with the narrowest leaves was Grahovo, with a mean leaf width of $35.79 \mathrm{~mm}$, while the Bugojno provenance had the widest leaves, with a mean value of $40.03 \mathrm{~mm}$. 
Table 4. Variance analysis of leaf width of natural progeny, by provenance $(\mathrm{Xsr} .=$ arithmetic mean, St.dev. $=$ standard deviation, $\mathrm{VC}=$ variance coefficient)

Tabela 4. Analiza varijanse širine listova prirodnog podmlatka po provenijencijama (Xsr. $=$ aritmetička sredina, St.dev. = standardna devijacija, VK= varijacioni koeficijent)

\begin{tabular}{|l|l|c|c|c|c|c|}
\hline No. & Provenance & $\mathrm{N}$ & Xsr. (mm) & St.dev. & VC (\%) & $\begin{array}{c}\text { Duncan } \\
\text { group }\end{array}$ \\
\hline 1. & Bos.Grahovo & 30 & 35.79 & 2.52 & 7.03 & $\mathrm{a}$ \\
\hline 2. & Olovo & 30 & 37.40 & 3.49 & 9.33 & $\mathrm{~b}$ \\
\hline 3. & Posušje & 30 & 38.06 & 2.30 & 6.04 & $\mathrm{~b}$ \\
\hline 4. & Bužim & 30 & 38.24 & 1.86 & 4.87 & $\mathrm{~b}$ \\
\hline 5. & Bugojno & 30 & 40.03 & 2.53 & 6.31 & $\mathrm{c}$ \\
\hline \multicolumn{2}{|l|}{ Sum/mean value } & 150 & 37.90 & 2.54 & 6.72 & - \\
\hline
\end{tabular}

Significance level 0.05

As table 4 shows, variance analysis revealed statistically significant differences between the provenances studied as regards leaf width of natural progeny. The provenances formed three separate Duncan groups, the first the Bosansko Grahovo provenance, the second the Olovo, Posušje and Bužim provenances, and the third the Bugojno provenance.

Unlike the leaf width of the natural progeny, where the Bugojno provenance had the widest leaves, seedlings of the same provenance had the narrowest leaves, followed by Bužim. The seedlings of Banja Luka provenance had the widest leaves, while those from the Olovo provenance were slightly narrower.

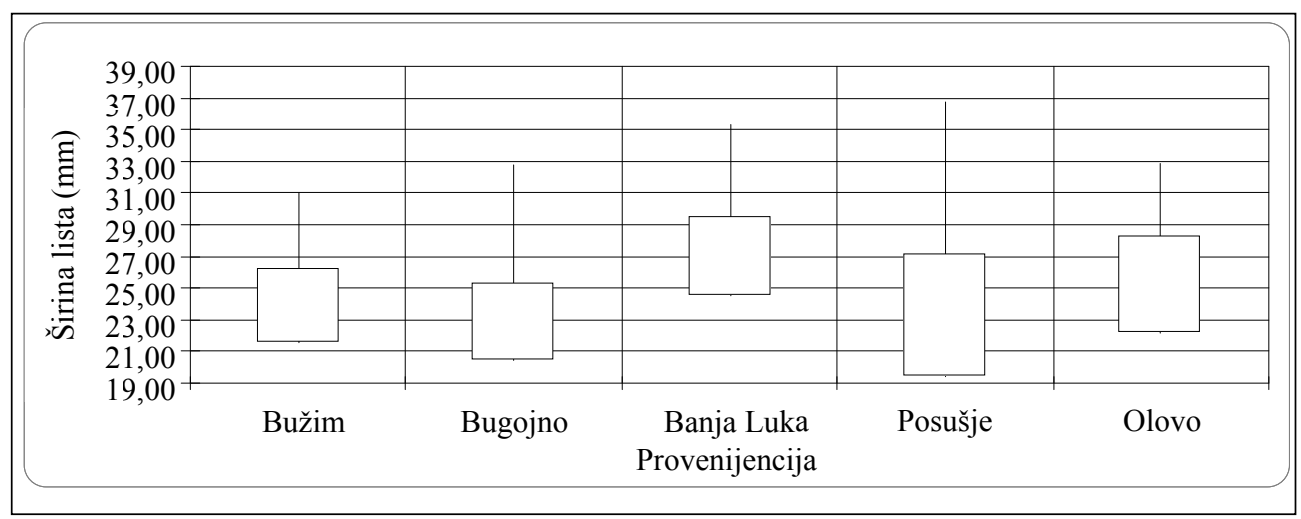

Chart 4. Width of leaves of seedlings by provenance

Grafikon 4. Širina listova klijanaca po provenijencijama 
Table 5. Variance analysis of leaf width of seedlings, by provenance (Xsr.= arithmetic mean, St.dev. $=$ standard deviation, $\mathrm{VC}=$ variance coefficient)

Tabela 5. Analiza varijanse širine listova klijanaca po provenijencijama (Xsr. $=$ aritmetička sredina, St.dev. $=$ standardna devijacija, $V K=$ varijacioni koeficijent)

\begin{tabular}{|l|l|c|c|c|c|c|}
\hline No. & Provenance & $\mathrm{N}$ & $\begin{array}{c}\text { Xsr. } \\
(\mathrm{mm})\end{array}$ & St.dev. & VC (\%) & $\begin{array}{c}\text { Duncan } \\
\text { group }\end{array}$ \\
\hline 1. & Bugojno & 30 & 25.33 & 3.58 & 14.13 & $\mathrm{a}$ \\
\hline 2. & Bužim & 30 & 26.25 & 2.39 & 9.10 & $\mathrm{a}, \mathrm{b}$ \\
\hline 3. & Posušje & 30 & 27.14 & 4.36 & 16.05 & $\mathrm{~b}, \mathrm{c}$ \\
\hline 4. & Olovo & 30 & 28.25 & 2.54 & 9.00 & $\mathrm{c}, \mathrm{d}$ \\
\hline 5. & Banja Luka & 30 & 29.51 & 3.44 & 11.67 & $\mathrm{~d}$ \\
\hline \multicolumn{2}{|l|}{ Sum/mean value } & 150 & 27.29 & 3.26 & 11.99 & - \\
\hline
\end{tabular}

Significance level 0.05

The variance analysis the results of which are given in table 5 revealed differences in leaf width among seedlings of different provenance. The Bugojno provenance, with the narrowest leaves, and Banja Luka, with the widest, formed separate groups. However, there are no statistically significant differences in leaf width between the Bugojno and Bužim provenances or between the Banja Luka and Olovo provenances. The Posušje provenance does not differ in leaf width from the Bužim and Olovo provenances.

The presence of cilia on the leaf margins is a characteristic that was also determined on the leaves of the provenances studied.

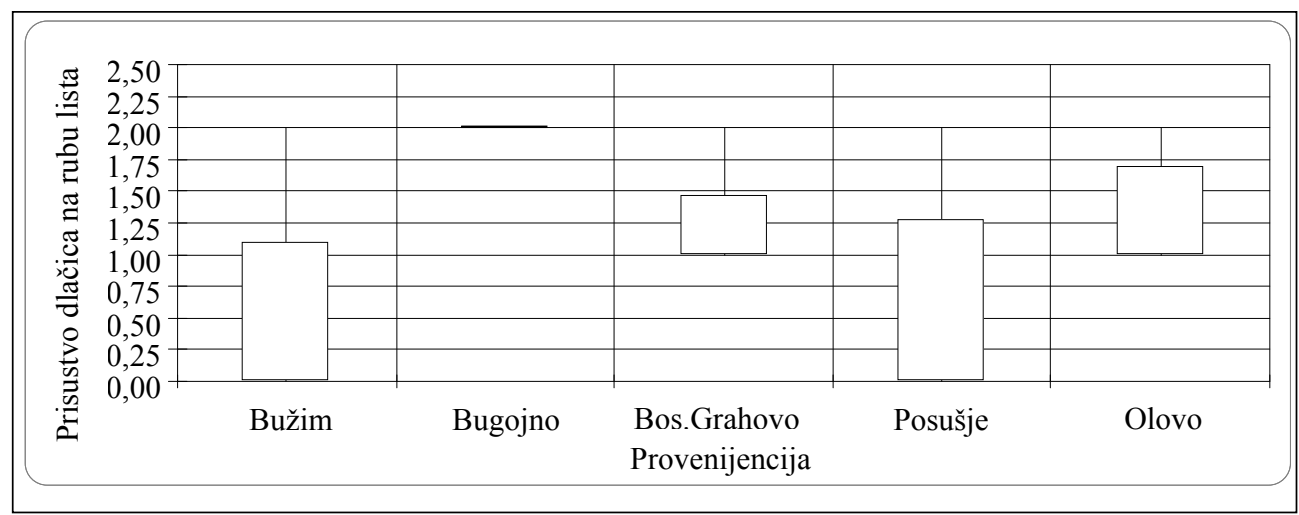

Chart 5. Presence of cilia on the leaf margins of natural progeny, by provenance

Grafikon 5. Prisustvo dlačica na rubu listova prirodnog podmlatka po provenijencijama

The presence of cilia on the leaf margins of natural progeny was most marked in the Bugojno provenance, as chart 5 shows. All leaves from the Bosansko Grahovo and Olovo provenances showed a significant presence of cilia on the leaf margins, 
with minor variations, while in the case of the Bužim and Posušje provenances, there were few cilia and considerable variability.

Table 6. Variance analysis of presence of cilia on leaf margins of natural progeny, by provenance (Xsr.= arithmetic mean, $\mathrm{St} . \mathrm{dev} .=$ standard deviation, $\mathrm{VC}=$ variance coefficient)

Tabela 6. Analiza varijanse prisustva dlačica na rubu lista prirodnog podmlatka po provenijencijama $(X s r .=$ aritmetička sredina, St.dev. $=$ standardna devijacija, $V K=$ varijacioni koeficijent)

\begin{tabular}{|l|l|c|c|c|c|c|}
\hline No. & Provenance & $\mathrm{N}$ & Xsr. & St.dev. & VC (\%) & $\begin{array}{c}\text { Duncan } \\
\text { group }\end{array}$ \\
\hline 1. & Bužim & 30 & 1.10 & 0.71 & 64.72 & $\mathrm{a}$ \\
\hline 2. & Posušje & 30 & 1.27 & 0.69 & 54.59 & $\mathrm{a}, \mathrm{b}$ \\
\hline 3. & Grahovo & 30 & 1.47 & 0.51 & 34.60 & $\mathrm{~b}, \mathrm{c}$ \\
\hline 4. & Olovo & 30 & 1.70 & 0.47 & 27.42 & $\mathrm{c}$ \\
\hline 5. & Bugojno & 30 & 2.00 & 0.00 & 0.00 & $\mathrm{~d}$ \\
\hline Sum/mean value & 150 & 1.51 & 0.48 & 36,27 & - \\
\hline
\end{tabular}

Significance level 0.05

$\mathrm{F}=12.9815$

Table 6 sets out the results of the variance analysis for the presence of cilia on the leaf margins of natural progeny. There is considerable variability within the provenances in the case of this characteristic. The variance coefficients are quite large - as high as $64.72 \%$ in the case of the Bužim provenance - with the exception of the Bugojno provenance, where all the leaves examined were extremely ciliate, with no variation. The Duncan test also confirmed the intra-provenance variability. The provenances formed four Duncan groups. Bužim formed one group, with the least presence of cilia, Bugojno another, with the most, and Olovo a third, with high ciliate values.

The presence of cilia on the leaf margins of seedlings was observed in two of the five provenances studied - the leaves of seedlings of Bužim and Banja Luka provenance.

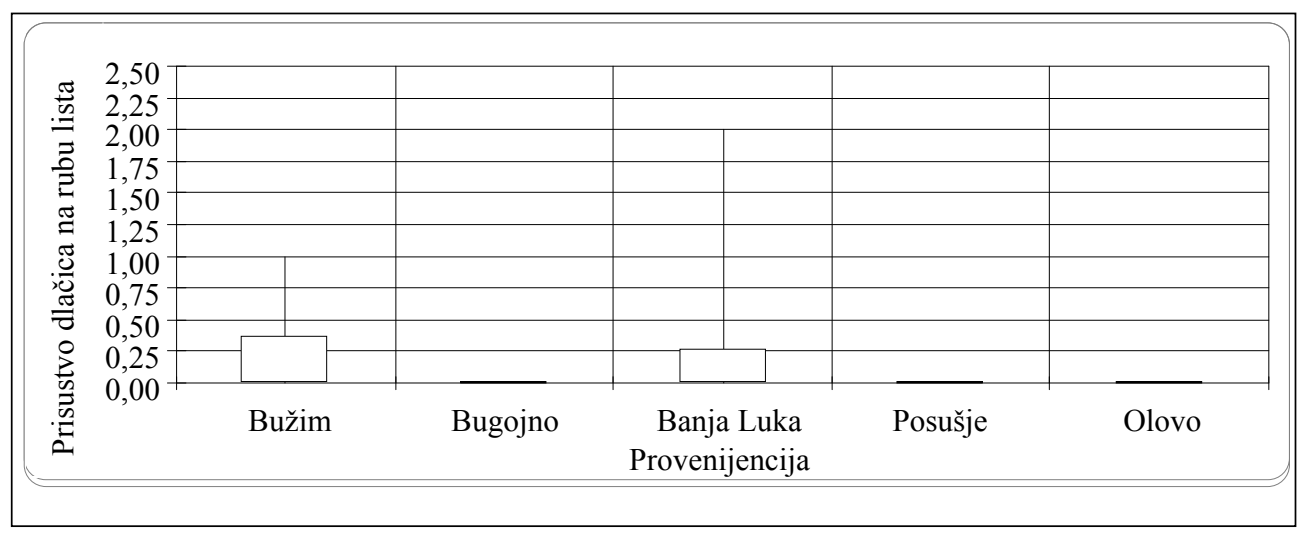

Chart 6. Presence of cilia on the leaf margins of seedlings, by provenance

Grafikon 6. Prisustvo dlačiva na rubu lista klijanaca po provenijencijama 
Table 7. Variance analysis of presence of cilia on the leaf margins of seedlings, by provenance (Xsr.= arithmetic mean, St.dev.= standard deviation, $\mathrm{VC}=$ variance coefficient)

Tabela 7. Analiza varijanse prisustva dlačica na rubu lista klijanaca po provenijencijama $(X s r .=$ aritmetička sredina, St.dev. $=$ standardna devijacija, $V K=$ varijacioni koeficijent $)$

\begin{tabular}{|c|c|c|c|c|c|c|}
\hline No. & Provenance & $\mathrm{N}$ & Xsr. & St.dev. & VC (\%) & $\begin{array}{c}\text { Duncan } \\
\text { group }\end{array}$ \\
\hline 1. & Bugojno & 30 & 0.00 & 0.00 & 0.00 & $\mathrm{a}$ \\
\hline 2. & Posušje & 30 & 0.00 & 0.00 & 0.00 & $\mathrm{a}$ \\
\hline 3. & Olovo & 30 & 0.00 & 0.00 & 0.00 & $\mathrm{a}$ \\
\hline 4. & Banja Luka & 30 & 0.27 & 0.52 & 195.31 & $\mathrm{~b}$ \\
\hline 5. & Bužim & 30 & 0.37 & 0.49 & 133.67 & $\mathrm{~b}$ \\
\hline \multicolumn{2}{|c|}{ Sum/mean value } & 150 & 0.13 & 0.20 & 65.80 & - \\
\hline
\end{tabular}

Significance level 0.05

$\mathrm{F}=9.18876$

Variance analysis determined the population variability. Table 7 shows that there is great inter-provenance variability in the case of this characteristic. Major variance coefficients were identified for Bužim - 133.67\% - and Banja Luka $195.31 \%$. The results of the Duncan test also revealed inter-provenance variability. The provenances formed two groups with statistically significant differences. One group consists of the Bugojno, Posušje and Olovo provenances, and the other of the Banja Luka and Bužim provenances.

\section{DISCUSSION - Diskusija}

Since the Balkan peninsula is the refuge habitat of beech, from which it began to spread to northern and western Europe after the ice age, it is clear that beech in the Balkans is of great age, and also that selection has been taking place for thousands of years, with the formation of many local races and ecotypes, which may be one of the causes of the polymorphism of beech in this part of the world. (URECHIATU, 1992).

Little research has been carried out in Bosnia and Herzegovina on the morphological characteristics of beech leaves. This paper sets out the results of a study of the morphological characteristics of leaves from natural progeny from the provenances studied, and of leaves from seedlings raised from seed from the same provenances. The ultimate aim of the research was to determine whether there were morphological differences among beech leaves in Bosnia and Herzegovina and, if so, whether these differences were dictated by the habitat conditions of the provenances or by heredity.

Nine parameters were measured to provide detailed results of the variability of Bosnian beech leaves: leaf length, leaf blade length, petiole length, leaf width, distance from the tip to the widest point of the leaf, petiole thickness, the presence of cilia on the leaf margins, the angle of insertion of the second right-hand vein, and the 
surface area of the leaf, and the coefficient of form, as the ratio between leaf blade width and length, was calculated.

The results obtained for leaf length lie within the interval limits cited by TRINAJSTIĆ (2003) for European beech in Croatia. Our measurements and data processing resulted in an average leaf-length value of $6.61 \mathrm{~cm}$ for natural progeny and $4.73 \mathrm{~cm}$ for seedlings, as compared with the interval cited by Trinajstić of 4 to $12 \mathrm{~cm}$. According to ŠILIĆ (2005), the interval limits for leaf length for European Beech in Bosnia and Herzegovina are similar, ranging from 5 to $12 \mathrm{~cm}$.

Our results for leaf width of Bosnian beech are 3.79 for natural progeny and $2.73 \mathrm{~cm}$ for seedlings. The values cited by ŠILIĆ (2005) for this feature are 3 to $8 \mathrm{~cm}$, and by Trinajstić, 2.5 to $8 \mathrm{~cm}$. This shows that our results do not differ greatly from those of these two researchers in our own and neighbouring countries, confirming the variability of beech in this part of the world on the basis of the morphological characteristics of the leaf.

The analysis of all ten leaf characteristics studied on natural progeny revealed that there is no great intra-provenance variability in the individual characteristics, as shown by the small and almost equal variance coefficients. The only characteristic to display a variance coefficient greater than $12 \%$ is the presence of cilia on the leaf margins, where the average variance coefficient is $36.27 \%$. Variance analysis revealed significant inter-provenance variability for most characteristics. Duncan testing produced two or three groups of the five provenances studied with statistically significant differences for each of the characteristics examined.

Observation of all these leaf characteristics in the case of seedling leaves, and the results arrived at after analyzing them, revealed that for certain characteristics there were greater intra-provenance variability and higher variance coefficients than in the case of leaves from natural progeny. Duncan testing also revealed greater interprovenance differences, which may be explained by the fact that the leaves for this analysis were taken from one-year-old seedlings, in which juvenile variability is more pronounced.

No significant correlations were identified from the analysis of the data for the leaf characteristics of natural progeny and seedlings of the same provenance. These results suggest just one conclusion: that the morphological characteristics are not the result of heredity, but are formed under the influence of the habitat conditions of different beech provenances. The results also indicate that within its natural range in Bosnia and Herzegovina, beech is a fairly variable and adaptive species. This can undoubtedly be explained by the age of beech in this part of the world (the glacial refuges of beech are the Pyrenean, Apennine and Balkan peninsulas, PINTARIĆ, 2002) and the juvenility of the seedling leaves sampled, which displayed great variability of form and size. 


\section{CONCLUSION - Zaključak}

The morphological leaf characteristics were determined on the leaves of natural progeny (to a height of $1.30 \mathrm{~m}$ ) and of nursery-raised seedlings.

- The longest leaves of natural progeny were recorded on leaves of Olovo provenance $(68.71 \mathrm{~mm})$ and the shortest on those of Grahovo provenance $(63.77$ $\mathrm{mm})$. The longest leaves of seedlings were recorded on leaves of Banja Luka provenance $(52.88 \mathrm{~mm})$ and the shortest on those of Bugojno provenance (44.49 $\mathrm{mm})$.

- The widest leaves of natural progeny were recorded on leaves of Bugojno provenance $(40.03 \mathrm{~mm})$ and the narrowed on those of Bosansko Grahovo provenance $(35.79 \mathrm{~mm})$. The widest leaves of seedlings were recorded on leaves of Banja Luka provenance $(29.51 \mathrm{~mm})$ and the narrowest on those of Bugojno provenance $(25.33 \mathrm{~mm})$.

- The ratio between leaf width and leaf blade length was taken as the indicator of shape. The most elongated leaves of natural progeny were those of Bugojno provenance, and the most rounded, those of Posušje provenance. Rounded leaves from seedlings were recorded on those of Posušje provenance, and elongated leaves on those of Banja Luka provenance.

- No correlations were identified between the morphological characteristics of leaves from natural progeny and from seedlings nursery-raised from seed from the same provenance, suggesting that the morphological characteristics examined are not the result of heredity.

\section{REFERENCES - Literatura}

ARnswaldt, H. J. (1950): Die wipfelschaftige Buche. Allg. Forstz., 5 (23): 265 - 266.

BEZAČINSKÝ, H. (1975): Výskum optimálnej štruktúry, vývoja a pestovania hospodárskych porastov vo fáze dospievania a obnovy. Etapa: Bučiny východného Slovenska. Lesn. Fak. VŠLD, Zvolen (research report), str. 255.

KraHL-Urban, J. (1953): Baumtypen bei Eichen und Buchen Allg. Forstz., 8: 245 248.

Mišić, V. (1956): Individualni polimorizam lista balkanske bukve u okviru jednog drveta. Zbornik radova Institut za ekologiju i biogeografiju Srpske akademije nauka., 6 (4): 3 - 25. Beograd.

Mıšı́́, V. (1957): Varijabilitet i ekologija bukve u Jugoslaviji. Zbornik radova Biološkog instituta N. R. Srbije, Monographiae, 1: 1 - 181, Beograd. 
MuCHS, H. J. (1986): Variability, provenance research, breeding, vegetative proagation, and gene conservation of beech. IUFRO Cong. Ljubljana, Div. I, Vol. II: $700-702$.

PagAN, J. (1968): Premenlivost morfologických znakov listov buka na Slovensku. Zbor. ved. Prác Lesn. Fak. VŠLD, 10 (1): 15 - 39, Zvolen.

PINTRIĆ, K. (2002): Šumsko-uzgojna svojstva i život važnijih vrsta šumskog drveća, Udruženje šumarskih inženjera i tehničara Federacije Bosne i Hercegovine (UŠIT), Sarajevo

RICHTER, J. (1990): Kronentypen bei der Rotbuche, Allg. Forst- u Jagdztg. 161: 11-14.

RZEZNIK, Z. (1976): Badania nad zmiennościa buka zwyczajnego (Fagus sylvatica L.) polskich proveniencji Rocz. Akad. roln., 72: 1-37.

ŠııIĆ, Č. (2005): Atlas dendroflore (drveće i grmlje) Bosne i Hercegovine, Franjevačka kuća Masna Lika, Čitluk, 114 str.

Teissier Du Cross, E., J. Kleinschmit, P. Azeouf, Hoslin, R. (1980): Spiral grain in Beech. Variability and heredity. Silvea Genet., 29 (1): 5 - 13.

URECHIATU, M. (1992): Beitrag über Untersuchungen an 77 Populationen der rumänischen Buche. Kongres zum Thema "Buche", 1992. Pamplona, Spanien.

VESELÝ L. (1977): Zmeny štruktúru a moefologických znakov v rastových fázech slovenských bučín. Lesn. Fak.VŠLD, (research report), Zvolen, str. 237.

\section{SAŽETAK}

U ovom radu istraživana je morfološka varijabilnost listova različitih provenijencija bukve (Fagus sylvatica L.) iz dijela prirodnog areala iz Bosne i Hwercegovine. Ciljevi istraživanja su bili, utvrditi da li postoji morfološka varijabilnost listova različitih provenijencija bukve u Bosni i Hercegovini, te utvrditi da li je morfologija lista kod bukve nasljedno svojstvo ili je pod uticajem uslova staništa na kojima pridolazi određena provenijencija.

Nakon provedenih istraživanja morfoloških obilježja lisata pojedinih provenijencija bukve, utvrđeno je prisustvo kako unutar provenijenične, tako i međuprovenijenične varijabilnosti pojedinih obilježja lista, kako kod prirodnog podmlatka tako i kod klijanaca proizvedenih iz sjemena pripadajućih provenijencija.

Što se tiče korelacionih veza pojedinih obilježja lista između listova prirodnog podmlatka i klijanaca proizvedenih u rasadniku (u jednakim uslovima staništa) nije zabilježena značajnija zavisnost. Ovo svakako navodi na jedinstven zaključak da većina morfoloških parametara lista bukve nisu nasljedna svojstva, te da je bukva na prostoru Bosne i Hercegovine dosta varijabilna i adaptivna vrsta. 